\title{
The First Slovak Experience with Second-line Vinflunine in Advanced Urothelial Carcinomas
}

\author{
Prvá slovenská skúsenost's použitím vinflunínu v druhej línii liečby \\ pokročilých urotelových karcinómov
}

\author{
Palacka P., Mego M., Obertova J., Chovanec M., Sycova-Mila Z., Mardiak J. \\ $2^{\text {nd }}$ Oncology Department, Medical School of Comenius University in Bratislava and National Cancer Institute, Bratislava, Slovak Republic
}

\begin{abstract}
Summary
Background: Based on the results of phase III trial, vinflunine was approved by European Medicines Agency in 2010 as second line treatment of advanced urothelial cancer in patients with good performance status (ECOG 0-1). The objective of this prospective observational study was to assess vinflunine treatment of advanced urothelial cancer patients in terms of progression free survival and overall survival, and to evaluate vinflunine toxicity. Patients and Methods: From April 2011 to June 2014 a total of 16 patients (100\%) with advanced urothelial cancer were treated with vinflunine. The median age was 62 years (range 43-80) and the median Karnofsky index was $90 \%$ (range $80-100 \%$ ). Thirteen patients (81.25\%) had urothelial bladder cancers, two patients (12.50\%) suffered from urothelial cancers of ureter, and one patient $(6.25 \%)$ had urothelial cancer of unknown origin (histology was obtained from liver metastasis). Histologically, all the lesions were grade 3 tumors (100\%). The number of metastatic sites ranged from 1-4 (median 3). Results: The effect of treatment was evaluated in accord with RECIST: two patients $(12.50 \%)$ obtained partial remission, three (18.75\%) stabilization, eight patients (50.00\%) progressed, and treatment was suspended in one case at patient's request. Vinflunine toxicity grade 3-4 included neutropenia in six patients (37.50\%), leukopenia in four patients $(25.00 \%)$, anemia in one patient $(6.25 \%)$, constipation in three patients $(18.75 \%)$, and febrile neutropenia in one patient (6.25\%). Median overall survival was 5.2 months (95\% Cl 3.4-8.8) and median progression-free survival was 2.3 months ( $95 \% \mathrm{Cl} 2.1-3.2)$. Conclusion: This study summarizes the first Slovak experience with vinflunine therapy. Our data confirmed the efficacy of vinflunine and its acceptable toxicity in the treatment of patients with advanced urothelial cancer previously treated with a platinum-based regimen.
\end{abstract}

\section{Key words}

advanced urothelial cancer - vinflunine - progression-free survival - overall survival - side effects
This study was supported by Grant VEGA $1 / 0614 / 12$.

Práca bola podporená grantom VEGA č. 1/0614/12. Autoři deklarují, že v souvislosti s předmětem studie nemaji žádné komerční zájmy.

The authors declare they have no potential conflicts of interest concerning drugs, products, or services used in the study.

Redakční rada potvrzuje, že rukopis práce splnil ICMJE kritéria pro publikace zasilané do biomedicínských časopisů.

The Editorial Board declares that the manuscript met the ICMJE "uniform requirements" for biomedical papers.

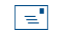

MUDr. Patrik Palacka, PhD.

$\mathrm{MPH}, \mathrm{MBA}$

$2^{\text {nd }}$ Oncology Department Medical School of Comenius University in Bratislava and National Cancer Institute

Klenova 1

83310 Bratislava 3

Slovak Republic

e-mail: info@onkol.sk

Submitted/Obdrženo: 30. 8. 2014

Accepted/Príijato: 13. 10. 2014

http://dx.doi.org/10.14735/amko2014429 


\begin{abstract}
Súhrn
Úvod: EMA (European Medicines Agency) schválila vinflunín v roku 2010 do 2. línie liečby pacientov s pokročilými urotelovými karcinómami v dobrom výkonnostnom stave (ECOG 0-1). Ciel'om tejto prospektívnej observačnej štúdie bolo vyhodnotit liečbu pacientov s pokročilými urotelovými karcinómami vinflunínom z pohladu prežívania bez progresie, celkového prežívania a toxicity. Pacienti a metódy: $V$ období apríl 2011-jún 2014 sme liečili vinflunínom 16 pacientov (100 \%) s pokročilými urotelovými karcinómami. Medián veku bol 62 rokov (rozsah 43-80), medián Karnofskeho indexu bol 90 \% (rozsah 80-100 \%). Trinást' pacientov $(81,25 \%$ ) malo urotelové karcinómy močového mechúra, dvaja pacienti (12,50 \%) urotelové karcinómy močovodu a jeden pacient (6,25 \%) urotelový karcinóm neznámeho pôvodu (histológia bola získaná z pečeňovej metastázy). Všetky primárne tumory boli stupňa 3 (100 \%). Počet metastatických miest bol v rozmedzí 1-4 (medián počtu 3). Výsledky: Účinok liečby bol hodnotený v súlade s kritériami RECIST: dvaja pacienti (12,50 \%) dosiahli parciálnu remisiu, traja pacienti (18,75 \%) stabilizáciu, osem pacientov (50 \%) progredovali priamo na liečbe a v jednom prípade bola terapia predčasne ukončená na žiadost' pacienta. Toxicita vinflunínu stupňa 3-4 zahrňovala neutropéniu u šest' pacientov (37,50 \%), leukopéniu u štyroch chorých (25,00\%), anémiu u jedného pacienta (6,25 \%), zápchu u troch chorých (18,75 \%) a febrilnú neutropéniu u jedného pacienta (6,25 \%). Medián celkového prežívania bol 5,2 mesiacov (95\% Cl 3,4-8,8), medián prežívania bez progresie 2,3 mesiace (95\% Cl 2,1-3,2). Záver: Táto štúdia predstavuje prvú slovenskú skúsenost’ s liečbou vinflunínom. Naše údaje potvrdzujú účinnost' liečby pacientov s pokročilými urotelovými karcinómami predliečenými platinovým režimom vinflunínom s akceptovatelnou toleranciou.
\end{abstract}

Klúčové slová

pokročilý urotelový karcinóm - vinflunín - preživanie bez progresie - celkové prežívanie - nežiaduce účinky

\section{Introduction}

Bladder cancer is the most common malignancy of the urinary system. In 2007, bladder cancer represented $3.9 \%$ of all malignant tumours $(n=511)$ in Slovak Republic (in comparison to 1.827 cases (5\%) diagnosed in Czech Republic at that time), the standardized incidence was $15.0 / 100,000(22.4 / 100,000$ in Czech Republic), and mortality in men progressed to $5.37 / 100,000$ (191 cases) (5.9/100,000 (507 cases) in Czech Republic). In both countries, slow, yet steady increase of incidence and mortality was registered in the last three decades. Just recently, mortality began to display ahe tendency towards stabilization [1].
MVAC regimen (including methotrexate, vinblastine, doxorubicin, cisplatin) is considered to be the standard of first-line treatment in patients with advanced urothelial bladder carcinoma [2,3]. Dose-dense MVAC with granulocyte colony-stimulating factor (G-CSF) support increased complete response rate and improved progression-free survival (PFS) in phase III studies, however, no overall survival (OS) improvement was achieved $[4,5]$. Another phase III study [6] showed GC (gemcitabine and cisplatin) non-inferiority to MVAC with no significant difference in response rates (49 vs. $46 \%$, respectively), time to progression (7.4 vs. 7.4 months, respectively), or OS (13.8 vs. 14.8 months, respectively). Grade 3-4 side effects were less frequent in patients treated with GC. Five-year survival rate was comparable in both groups of patients (15 vs. $13 \%$, respectively) [7]. Due to its comparable efficacy and better side-effect profile, GC became a standard regimen used in the treatment of advanced bladder cancer in majority of EU countries.

There was not any standard approach for second-line treatment of advanced bladder cancer established until recently. Many cytostatics were tested in single-agent setting (phase II studies, Tab. 1) e.g. gemcitabine [8,9], paclitaxel [10], ifosfamide [11,12],

Tab. 1. Monochemotherapy in the second-line treatment of advanced bladder cancer.

\begin{tabular}{|c|c|c|c|c|c|c|}
\hline Study & Regime & Phase & $\mathbf{n}$ & RR (\%) & TTP (months) & OS (months) \\
\hline Lorusso et al [8] & gemcitabine & ॥ & 35 & 23 & 3.8 & 5.0 \\
\hline Albers et al [9] & gemcitabine & ॥ & 30 & 11 & 4.9 & 8.7 \\
\hline Vaughn et al [10] & paclitaxel & ॥ & 31 & 10 & 2.2 & 7.2 \\
\hline Pronzato et al [11] & ifosfamide & ॥ & 20 & 5 & $\mathrm{nr}$ & $\mathrm{nr}$ \\
\hline Witte et al [12] & ifosfamide & $\|$ & 56 & 20 & 2.5 & 5.5 \\
\hline McCaffrey et al [13] & docetaxel & ॥ & 20 & 13 & $\mathrm{nr}$ & 9.0 \\
\hline Sweeney et al [14] & pemetrexed & $\|$ & 47 & 28 & 2.9 & 9.6 \\
\hline Dreicer et al [15] & ixabepilone & II & 45 & 12 & 2.7 & 8.0 \\
\hline Bellmunt et al [25] & vinflunine & III & 370 & 9 & 3.0 & 6.9 \\
\hline
\end{tabular}


Tab. 2. Combination chemotherapy in the second-line treatment of advanced bladder cancer.

\begin{tabular}{|c|c|c|c|c|c|}
\hline Study & Regime & Phase & $\mathbf{n}$ & $\mathbf{R R}(\%)$ & OS (months) \\
\hline Krege et al [16] & docetaxel + ifosfamide & ॥ & 22 & 25 & 4.0 \\
\hline Lin et al [17] & gemcitabine + ifosfamide & II & 23 & 22 & 4.8 \\
\hline Bellmunt et al [18] & methotrexate + paclitaxel & ॥ & 20 & 32 & 5.0 \\
\hline Sternberg et al [19] & gemcitabine + paclitaxel & II & 41 & 60 & 14.4 \\
\hline Fechner et al [20] & gemcitabine + paclitaxel & ॥ & 27 & 44 & 13.0 \\
\hline Vaishampayan et al [21] & paclitaxel + carboplatin & ॥ & 44 & 16 & 6.0 \\
\hline Pagliaro et al [22] & ifosfamide + gemcitabine + cisplatin & II & 49 & 41 & $\mathrm{nr}$ \\
\hline Chen et al [23] & gemcitabine + docetaxel + carboplatin & $\mathrm{I} / \mathrm{II}$ & 20 & 45 & $\mathrm{nr}$ \\
\hline Tu et al [24] & paclitaxel + cisplatin + methotrexate & ॥ & 25 & 40 & $\mathrm{nr}$ \\
\hline
\end{tabular}

$\mathrm{n}$ - number of patients, RR - response rate, OS - overall survival, $\mathrm{nr}$ - not reached

docetaxel [13], pemetrexed [14], and ixabepilone [15] with response rates (RR) ranging from 5 to $28 \%$ (ifosfamid and pemetrexed, respectively), time to progression (TTP) 2.2-4.9 months (paclitaxel and gemcitabine, respectively), and OS from 5.0 months to 9.6 months (gemcitabine and pemetrexed, respectively). Nevertheless, the improvement of both RR and OS was reached mainly with combination chemotherapy (Tab. 2) [16-24]. Particularly, combination of gemcitabine and paclitaxel [19] showed $60 \%$ RR and OS of 14.4 months.

Vinflunine (VFL) is a third-generation microtubule inhibitor of the vinca alcaloid class with low and reversible affinity to tubuline. Prior to its clinical evaluation, there was a high anti-tumour activity proven in vitro. In a phase III study [25], a total of 370 patients were randomly assigned either to VFL plus best supportive care (BSC), $\mathrm{n}=253$ or BSC alone, $n=117)$. In the response-evaluable population ( $n=357$ ), the median OS was significantly higher in patients with $\mathrm{VFL}+\mathrm{BSC}$ in comparison to the BSC group (6.9 vs. 4.3 months, respectively, $\mathrm{p}=0.040$ ). Overall response rate, disease control, and PFS were all favouring VFL + BSC on a statistically significant level $(p=0.006, p=0.002$ and $p=0.001$, respectively). Moreover, the advantage of vinflunine treatment is a predictable and manageable noncumulative toxicity (25\%), comprising mainly neutropenia (50\%), anemia (19\%), fatigue (19\%), constipation (16\%) and febrile neutropenia (6\%).

The objective of this prospective observational study was to assess the role of vinflunine in the treatment of advanced urothelial cancer in terms of PFS and OS. Another goal was to evaluate toxicity profile of vinflunine, and to compare the results with available literature. This study introduces the first experience with vinflunine therapy in Slovak Republic.

\section{Characteristics of patients}

From April 2011 to June 2014, 16 patients $(100 \%)$ with advanced urothelial cancer (women: $\mathrm{n}=3,18.75 \%$; men: $\mathrm{n}=13,81.25 \%$ ) were administered vinflunine as second-line therapy at the $2^{\text {nd }}$ Oncology Department, Medical School of Comenius University in Bratislava and National Cancer Institute. All patients underwent prior treatment with GC (gemcitabine and cisplatin). The median age was 62 years (range 43-80), and the median Karnofsky performance status at the beginning of treatment was 90\% (range $80-100 \%$ ). Thirteen patients (81.25\%) had urothelial bladder cancers, two patients $(12.50 \%)$ suffered from urothelial cancers of ureter, and one patient $(6.25 \%)$ had urothelial cancer of unknown origin (histology was obtained from liver metastasis). Histologically, all primary lesions were grade 3 tumors (100\%). The number of metastatic sites ranged from 1-4 (median 3). There were several poor prognostic factors identified in the second-line (Graph 1) treatment settings, such as hemoglobin $\geq 10 \mathrm{~g} / \mathrm{dl}$ in four patients $(25.0 \%)$, liver involvement in seven patients (43.8\%), and ECOG-PS $\geq 1$ in four patients (25.0\%).

\section{Results}

All the patients were administered vinflunine monotherapy in dose of $320 \mathrm{mg} / \mathrm{m}^{2}$ every three weeks, the number of cycles ranged from 2 to 14 (median 4), and total vinflunine dose was $2,473.33 \pm 2,108.48 \mathrm{mg}$. The tumor response was evaluated after four, eight and twelve cycles in accord with the RECIST [26]: two patients (13.33\%) achieved partial response, three patients (20.00\%) obtained stabilization, eight patients $(53.33 \%)$ progressed on the treatment, and therapy was terminated in one case at patient's request, hence was not included in the analysis. The objective response rate was $13.33 \%$. Grade 3 or 4 toxicities associated with vinflunine administration included neutropenia in six patients (37.50\%), leukopenia in four patients $(25.00 \%)$, one patient experienced anemia (6.25\%), constipation occured in three patients $(18.75 \%)$, and febrile neutropenia (FN) in one patient $(6.25 \%)$ with a need of further granulocyte colony-stimulating factor (GCS-F) pegfilgrastim prevention every 3 weeks, 48 hours after vinflunine application. Subsequently, no FN events were observed. In the study population, the median PFS (Graph 2) was 
4 supgroups formed, based on the presence of $0,1,2$ or 3 prognostic factors strata:

$\begin{array}{llll}\text { 一 risk }=0 & \cdots \text { censored risk }=0 & & \text { - risk }=1 \\ \text { - risk }=2 & \cdots \text { censored risk }=2 & & \text { - risk }=3\end{array} \quad \cdots$ censored risk $=1$

median (months) $95 \% \mathrm{Cl}$ : risk $0=11.5(9.3$ to $17.9 ; \mathrm{n}=65)$ risk $1=7.3(5.6$ to $8.3 ; n=64)$

$\begin{array}{ll}\begin{array}{l}\text { Variables } \\ \text { at baseline }\end{array} & \begin{array}{l}\text { Ref. } \\ \text { category }\end{array} \\ \text { haemoglobin } & <10 \mathrm{~g} / \mathrm{dl} \\ \text { liver } & \text { no } \\ \text { involve- } & \text { involve- } \\ \text { ment } & \text { ment } \\ \text { ECOG-PS } & \geq 1\end{array}$

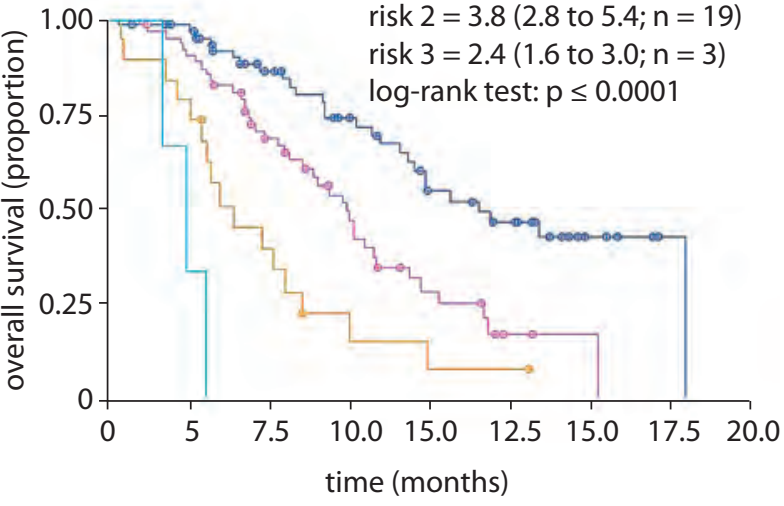

Kaplan-Meier estimates for each risk group

Graph 1. Prognostic factors in second-line treatment of advanced bladder cancer [27].

2.3 months $(95 \% \mathrm{Cl} 2.1-3.2)$, and the median OS (Graph 3) was 5.2 months (95\% $\mathrm{Cl}$ 3.4-8.8). At the time of final analysis only one patient remained alive; the median follow-up was 5.2 months $(95 \% \mathrm{Cl}$ $0.6-16.3)$.

\section{Discussion}

Bellmunt et al introduced the first and only randomized phase III study [25] conducted in platinum-pretreated patients with TCCU (advanced transitional cell carcinoma of the urothelial tract) using vinflunine in the second-line setting. With reference to this study, which provided the IB level of evidence, EMEA (European Medicines Agency) has approved vinflunine in 2010. However, opponents of this study [25] argue that survival improvement of 2.6 months might be statistically significant yet, from a clinical point of view it remains irrelevant. This might be one of the reasons why FDA (Food and Drug Administration) has never approved vinflunine as a standard second-line treatment of the advanced bladder cancer in the US. The analysis of the above-mentioned results [25], revealed several positive prognostic factors (Graph 1), such as hemoglobin level higher than $10 \mathrm{~g} / \mathrm{dl}$, the absence of liver metastases, and ECOG performance status $0-1$ [27]. It is of question, whether these prognostic factors might be considered sufficient for the efficacy evaluation of a new drug like vinflunine. The analysis of 179 patients with at least one measurable target lesion showed that patients with tumor reduction $\geq 10 \%$ obtained significantly better OS than patients with tumor shrinkage lower than $10 \%$ ( 11,3 vs. 6,9 months, $p=0,0224)$. Still, even a small tumor reduction (ranging from 10\%) in vinflunine treated patients led to a particular survival improvement. Hence, a decrease in SLD (sum of the longest diameter) in target lesions by about $10 \%$ might represent a promising early survival predictor in patients treated with vinflunine. SLD decreasing by $\geq 10 \%$ at the first CT control appears to be a better early outcome predictor than RECIST itself, however this remains to be confirmed by future studies.

In this prospective observational study, there were 16 patients with advanced urothelial cancer treated with second-line vinflunine in the standard

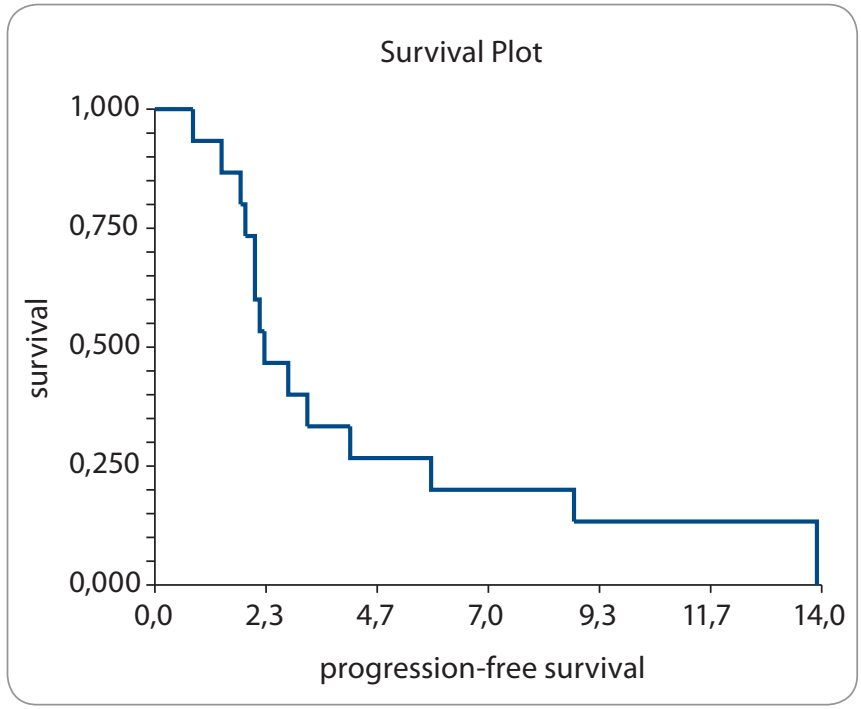

Graph 2. Progression-free survival (PFS) in the study group.

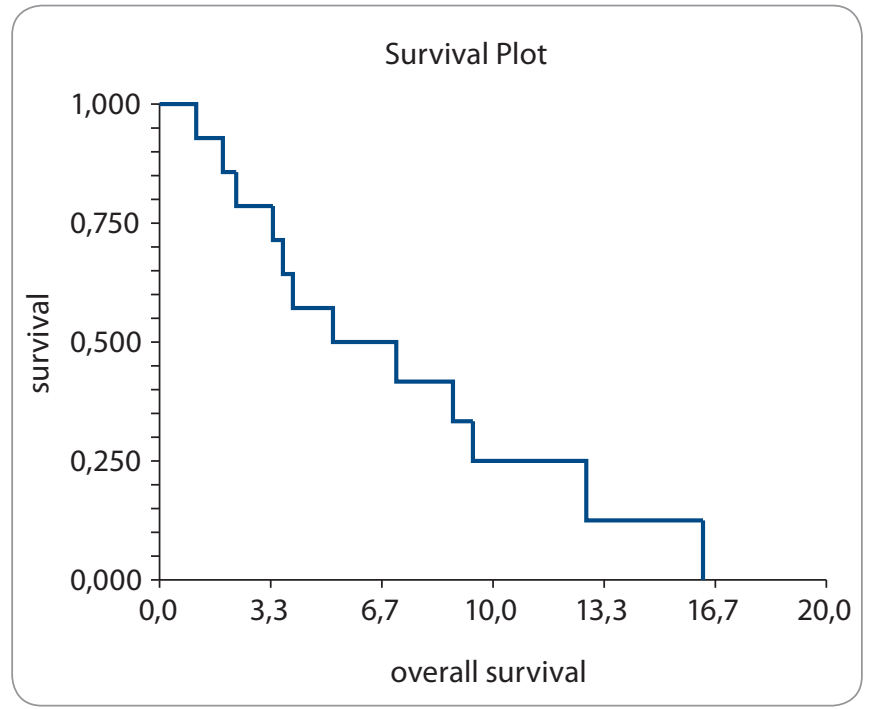

Graph 3. Overall survival (OS) in the study group. 
dose. The objective response rate observed in this study was $13.33 \%$, which is comparable to $8.60 \%$ reported by Bellmunt et al [25]. Likewise, the tocixity spectrum was similar, with neutropenia grade 3-4 being the most common side effect $(37.50 \%$ in our study vs. $50.00 \%$ in Bellmunt's study), whereas the incidence of febrile neutropenia was relatively low $(6.25 \%$ in this study vs. $6.0 \%$ in the study of Bellmunt et al). Constipation (grade 3-4) - the typical side effect of vinca alcaloids - was present in 18.75 patients (vs. $16,1 \%$ in Bellmunt's study). Median PFS of 2.3 months and median OS of 5.2 months obtained in this study was shorter than in the study of Bellmunt et al (3.0 months for PFS and 6.9 months for OS). This might be due to a smaller study population, as well as the pioneer nature of this prospective observational study of vinflunine treatment within Slovak boundaries.

In conclusion, single-agent vinflunine might be considered a standard of second-line treatment for patients with advanced urothelial cancer with good performance status (ECOG 0 a 1). The first Slovak experience confirms the effectivity of this treatment in terms of PFS and OS, with acceptable and well manageable toxicity profile. For patients who do not meet indication criteria, paclitaxel monotherapy could be considered with refference to a phase II study (Tab. 1). Best supportive care is optional for patients with poor performance status or when a patient refuses cytostatic treatment.

\section{References}

1. Ondrušová M, Ondruš D. Vybrané ukazovatele epidemiológie zhubných nádorov obličiek a močového mechúra v SR a ČR. Onkológia (Bratisl.) 2010; 5(5): 244-247. 2. Logothetis CJ, Dexeus FH, Finn L et al. A prospective randomized trial comparing MVAC and CISCA chemothe- rapy for patients with metastatic urothelial tumors. J Clin Oncol 1990; 8(6): 1050-1055.

3. Loehrer PJ Sr, Einhorn LH, Elson PJ et al. A randomized comparison of cisplatin alone or in combination with methotrexate, vinblastine, and doxorubicin in patients with metastatic urothelial carcinoma: a cooperative group study. J Clin Oncol 1992; 10(7): 1066-1073.

4. Sternberg CN, de Mulder PH, Schornagel JH et al. Ran domized phase III trial of high-dose-intensity methotrexate, vinblastine, doxorubicin, and cisplatin (MVAC) chemotherapy and recombinant human granulocyte Colony-stimulating factor versus classic MVAC in advanced urothelial tract tumors: European Organization for Research and Treatment of Cancer Protocol No. 30924. J Clin Oncol 2001; 19(10): 2638-2646.

5. Sternberg CN, de Mulder P, Schornagel JH et al. Seven year update of an EORTC phase III trial of high-dose intensity M-VAC chemotherapy and G-CSF versus classic $M-V A C$ in advanced urothelial tract tumours. Eur J Cancer 2006; 42(1): 50-54.

6. Von der Maase H, Hansen SW, Roberts JT et al. Gemcitabine and cisplatin versus methotrexate, vinblastine, doorubicin, and cisplatin in advanced or metastatic bladder cancer: results of a large, randomized, multinational, multicenter, phase III study. J Clin Oncol 2000; 18(17) 3068-3077.

7. Von der Maase $H$, Sengelov L, Roberts JT et al. Long-term survival results of a randomized trial comparing gemcitabine plus cisplatin, with methotrexate, vinblastine, doxorubicin, plus cisplatin in patients with bladder cancer. J Clin Oncol 2005; 23(21): 4602-4608.

8. Lorusso V, Polera CF, Antimi M et al. A phase II study of gemcitabine in patients with transitional cell carcinoma of the urinary tract previously treated with platinum. Italian Co-operative Group on Bladder Cancer. Eur J Cancer 1998; 34(8): 1208-1212.

9. Albers $P$, Siener R, Hartlein M et al. Gemcitabine monotherapy as second-line treatment in cisplatin-refractory transitional cell carcinoma - prognostic factors for response and improvement of quality of life. Onkologie 2002; 25(1): 47-52.

10. Vaughn DJ, Broome CM, Hussain M et al. Phase trial of weekly paclitaxel in patients with previously treated advanced urothelial cancer. J Clin Oncol 2002; 20(4): 937-940.

11. Pronzato P, Vigani A, Pensa F et al. Second line chemotherapy with ifosfamide as outpatient treatment for advanced bladder cancer. Am J Clin Oncol 1997; 20(5): 519-521.

12. Witte RS, Elson P, Bono B et al. Eastern Cooperative Oncology Group phase II trial of ifosfamide in the treatment of previously treated advanced urothelial carcinoma. J Clin Oncol 1997; 15(2): 589-593.

13. McCaffrey JA, Hilton S, Mazumdar M et al. Phase I trial of docetaxel in patients with advanced or metastatic transitional-cell carcinoma. J Clin Oncol 1997; 15(5): 1853-1857.

14. Sweeney CJ, Roth BJ, Kabbinavar FF et al. Phase ॥ study of pemetrexed for second-line treatment of tran- sitional cell cancer of the urothelium. J Clin Oncol 2006; 24(21): 3451-3457.

15. Dreicer R, Li S, Manola J et al. Phase 2 trial of epothilone B analog Bms-247550 (ixabepilone) in advanced carcinoma of the urothelium (E3800): a trial of the Eastern Cooperative Oncology Group. Cancer 2007; 110(4): 759-763.

16. Krege S, Rembrink V, Borgermann C et al. Docetaxel and ifosfamide as second line treatment for patients with advanced or metastatic urothelial cancer after failure of platinum chemotherapy: a phase 2 study. J Urol 2001; 165(1): 67-71.

17. Lin CC, Hsu CH, Huang CY et al. Gemcitabine and ifosfamide as a second-line treatment for cisplatin-refractory metastatic urothelial carcinoma: a phase II study. Anticancer Drugs 2007; 18(4): 487-491.

18. Bellmunt J, Cos J, Cleries Ret al. Feasibility trial of methotrexate-paclitaxel as a second line therapy in advanced urothelial cancer. Cancer Invest 2002; 20(5-6): 673-685. 19. Sternberg CN, Calabro F, Pizzocaro G et al. Chemotherapy with an every 2-week regimen of gemcitabine and paclitaxel in patients with transitional cell carcinoma who have received prior cisplatin-based therapy. Cancer 2001; 92(12): 2993-2998.

20. Fechner G, Siener R, Reimann M et al. Randomised phase II trial of gemcitabine and paclitaxel second-line chemotherapy in patients with transitional cell carcinoma (AUO Trial AB 20/99). Int J Clin Pract 2006; 60(1): 27-31.

21. Vaishampayan UN, Faulkner JR, Samll EJ et al. Phase II trial of carboplatin and paclitaxel in cisplatin-pretreated advanced transitional cell carcinoma: a Southwest Oncology Group study. Cancer 2005; 104(8): 1627-1632. 22. Pagliaro LC, Millikan RE, Tu SM et al. Cisplatin, gemcitabine, and ifosfamide as weekly therapy: a feasibility and phase II study of salvage treatment for advanced transitional-cell carcinoma. J Clin Oncol 2002; 20(13): 2965-2970. 23. Chen AC, Hovey E, Shelton $G$ et al. Phase I/II study of docetaxel (D), gemcitabine $(G)$, carboplatin $(C)$ in poor prognosis and previously treated patients (pts) with urothelial carcinoma (UTC). J Clin Oncol 2004; 22 (Suppl): 14 S. 24. Tu SM, Hossan E, Amato R et al. Paclitaxel, cisplatin and methotrexate combination chemotherapy is active in the treatment of refractory urothelial malignancies. J Urol 1995; 154(5): 1719-1722

25. Bellmunt J, Theodore C, Demkov T et al. Phase III trial of vinflunine plus best supportive care compared with best supportive care alone after a platinum-containing regimen in patients with advanced transitional cell carcinoma of the urothelial tract. J Clin Oncol 2009; 27(27): 4454-4461. doi: 10.1200/JCO.2008.20.5534.

26. Eisenhauer EA, Therasse P, Bogaerts J et al. New response evaluation criteria in solid tumours: revised RECIST guideline (version 1.1). Eur J Cancer 2009; 45(2): 228-247. doi: 10.1016/j.ejca.2008.10.026.

27. Bellmunt J, Choueiri TK, Fougeray $R$ et al. Prognostic factors in patients with advanced transitional cell carcinoma of the urothelial tract experiencing treatment failure with platinum-containing regimens. J Clin Oncol 2010; 28(11): 1850-1855. doi: 10.1200/JCO.2009.25.4599. 